\title{
Embrittlement and Corrosion Decay of a Cast Duplex Stainless Steel
}

\author{
João Vitor Silva Matias ${ }^{a}$, Sérgio Souto Maior Tavares ${ }^{b *}$, Juan Manuel Pardal', \\ Ruan Stevan de Almeida Ribeiro ${ }^{b}$ \\ anstituto Federal Fluminense, Campus São João da Barra, Núcleo de Ciência e Tecnologia dos \\ Materiais, BzR 356, KM 181, Perigoso, CEP: 28200-000, São João da Barra, RJ, Brazil \\ ${ }^{b}$ Escola de Engenharia, Universidade Federal Fluminense, Rua Passo da Pátria, 156, \\ CEP 24210-240, Niterói, RJ, Brazil \\ 'Programa de Pós graduação em Engenharia Mecânica (PGMEC), Universidade Federal Fluminense, \\ Rua Passo da Pátria, 156, CEP 24210-240, Niterói, RJ, Brazil
}

Received: January 18, 2017; Revised: June 14, 2017; Accepted: June 20, 2017

\begin{abstract}
Duplex stainless steels (DSS) are Fe-Cr-Ni-Mo alloys, with low carbon content, which have a favorable combination of mechanical properties and corrosion resistance. These characteristics are mainly attributed to a dual phase and refined microstructure, typical of these alloys, consisting of similar amounts of ferrite and austenite. For this reason, DSS are widely used in various segments of industry, especially in offshore applications. However, DSS components may have a decrease of their properties when they are exposed high temperatures, often due to incorrect manufacturing processes. Intermetallic phases may precipitate causing embrittlement and corrosion resistance decrease. This work presents the effects of short time aging at $475^{\circ} \mathrm{C}$ on the mechanical properties and localized corrosion resistance of a cast DSS. The results show that mechanical properties, such as toughness and hardness, are more susceptible to aging, having already been affected during the first 4 hours of heat treatment, while the corrosion was affected in $12 \mathrm{~h}$ of aging.
\end{abstract}

Keywords: duplex stainless steel, intergranular corrosion, alfa prime, $475^{\circ} \mathrm{C}$ embrittlement

\section{Introduction}

Duplex stainless steels (DSS) are Fe-Cr-Ni-Mo alloys with low carbon contents, often containing important additions of nitrogen. The optimum microstructure consists of equal quantities of ferrite $(\delta)$ and austenite $(\gamma)$ and no traces of other phases ${ }^{1,2}$. For instance, according to Norsok M-601 standard $^{3}$, the ferrite content percentage in weld metals must be within $30 \%$ and $70 \%$.

DSS have been extensively used in chemical, petrochemical and power generation industries ${ }^{4}$. This wide application is attributed to the high corrosion resistance, mechanical strength and high toughness obtained with the balanced dual phase microstructure ${ }^{5}$. However, when exposed to temperatures between $1000^{\circ} \mathrm{C}$ and $300^{\circ} \mathrm{C}$ the DSS become susceptible to a number of deleterious phase transformations, such as sigma and chi phase precipitation, carbides and nitrides precipitations at higher temperatures ${ }^{1}$. In the temperature range $970-650{ }^{\circ} \mathrm{C}$, precipitation of the sigma $(\sigma)$ and chi $(\chi)$ phases may occur, in addition to carbides and nitrides. In the 550 to $300{ }^{\circ} \mathrm{C}$ range, the main reaction is the alphaprime phase ( $\left.\alpha^{\prime}\right)$ precipitation by spinodal decomposition mechanism:

$$
\delta \rightarrow \alpha^{\prime}+\alpha^{\prime \prime}
$$

$\alpha$ ' is a Cr-rich nanometric phase, which causes embrittlement and hardening of DSS. This phenomena is called $475^{\circ} \mathrm{C}$ embrittlement or hardening because the higher kinetics of reaction (1) occurs at this temperature. Since $\alpha$ " corresponds

*e-mail: ssmtavares@terra.com.br to Cr-depleted regions, other consequence is the corrosion decay if the steel is exposed for long periods in the critical temperature range $\mathrm{e}^{3,6-9}$.

On the other hand, some previous works showed that short duration aging heat treatments at $475^{\circ} \mathrm{C}$ can be applied to wrought DSS to increase the hardness, mechanical strength and wear resistance ${ }^{10}$. It was observed that within $12 \mathrm{~h}$ of aging the decrease of toughness and corrosion resistance were very small or undetectable.

The purpose of this work was to characterize the toughness and corrosion resistance of a cast duplex stainless steel with inappropriate chemical composition. The effect of short duration aging at $475{ }^{\circ} \mathrm{C}$ was also evaluated.

\section{Materials and Methods}

The material used in this work comes from a tube with $10 \mathrm{~mm}$ of thickness produced by centrifugal casting, with chemical composition shown in Table 1. C, S and N were analyzed by combustion method, while the other elements were analyzed by plasma spectroscopy.

The material was solution treated at $1060{ }^{\circ} \mathrm{C}$ for $1 \mathrm{~h}$ and water quenched. After this treatment some specimens were cut and machined to the dimensions of sub-size Charpy impact specimens $\left(55 \times 10 \times 7.5 \mathrm{~mm}^{3}\right)^{11}$. Specimens for the double loop electrochemical potentiodynamic reactivation tests (DL-EPR) were cut and machined with approximate dimensions $15 \times 15 \times 10 \mathrm{~mm}^{3}$. Some specimens were subjected to heat treatments at $475^{\circ} \mathrm{C}$ for $4 \mathrm{~h}, 8 \mathrm{~h}$ and $12 \mathrm{~h}$, followed by water cooling. 
Table 1. Chemical composition (wt.\%) of the DSS investigated.

\begin{tabular}{|c|c|c|c|c|c|c|c|c|c|c|}
\hline $\mathrm{Cr}$ & $\mathrm{Ni}$ & Mo & $\mathrm{Mn}$ & $\mathrm{Si}$ & $\mathrm{N}$ & $\mathrm{Cu}$ & W & $\mathrm{C}$ & $\mathrm{P}$ & $\mathrm{S}$ \\
\hline 24.06 & 7.48 & 2.076 & 1.186 & 0.956 & 0.045 & 0.132 & 0.217 & 0.070 & 0.011 & 0.013 \\
\hline
\end{tabular}

The Charpy impact test was carried out at $-46^{\circ} \mathrm{C}$. After the tests some samples were selected to fractography in the stereo microscope (SEM). Vickers hardness test with $10 \mathrm{kgf}$ load were performed in samples cut from the broken Charpy specimens in regions unaffected by the fracture.

The DL-EPR tests were performed using a three electrode cell with working electrode, saturated calomel electrode (SCE) as reference and a Pt wire as counter-electrode. The test was controlled and the data were collected in a potentiostat-galvanostat $\mu$-AUTOLAB. The test solution was $2 \mathrm{M} \mathrm{H}_{2} \mathrm{SO}_{4}+0.01 \mathrm{M} \mathrm{KSCN}+0.5 \mathrm{M} \mathrm{NaCl}$ at room temperature. After stabilization of the open circuit potential the test was initiated. The potential was increased in the anodic direction with a sweep rate of $1 \mathrm{mV} / \mathrm{s}$ till $0.3 \mathrm{~V}_{\mathrm{SCE}}$. Then, the sweeping was reversed to the cathodic direction with the same sweeping rate. The degree of sensitization was measured by the ratio $\mathrm{Ir} / \mathrm{Ia}$, where Ir is the peak current of the reactivation (cathodic) loop and Ia is the activation peak of current of the activation (anodic) loop. The area of the work electrode exposed to the text was delimited with enamel. This area was not exactly the same for all specimens.

The microstructure was analyzed by optical and scanning electron microscopy. Specimens were prepared by grinding and etching with Beraha's solution $\left(80 \mathrm{ml} \mathrm{H}_{2} \mathrm{O}, 20 \mathrm{ml} \mathrm{HCl}\right.$, $0.3 \mathrm{~g}$ potassium metabissulfite). Specimens etched during the DL-EPR tests were also analyzed in the SEM.

\section{Results and Discussion}

\subsection{Chemical composition and Microstructural characterization}

Analyzing the chemical composition of Table 1, the steel does not fit in any commercial grade of duplex (DSS) or superduplex stainless steel (SDSS) of the ASTM A890 ${ }^{12}$ standard specifications for castings of austenitic-ferritic steels. $\mathrm{Cr}$ and Ni contents are typical of grade UNS J93404 (similar to wrought grade UNS S32750), but the Mo and N are lower than the minimum content specified for this grade. The Pitting Resistant Equivalent Number (PREN) of the steel calculated by the formulae PREN $=(\% \mathrm{Cr})+3.3(\% \mathrm{Mo}+0.5(\% \mathrm{~W}))+$ $16(\% \mathrm{~N})$ is 32 , typical of a duplex stainless steel. Another feature of the chemical composition is the high carbon content $(0.07 \%)$, much higher than the maximum specified for DSS UNS J92205 or SDSS UNS J93404.

Figure 1 shows the microstructure of the steel after the solution treatment. Ferrite $(\delta)$ volume fraction corresponds to $(54.5$ $\pm 1.0) \%$ and austenite corresponds to $(45.5 \pm 1.0) \%$. Deleterious phases were not detected in the specimens solution treated.

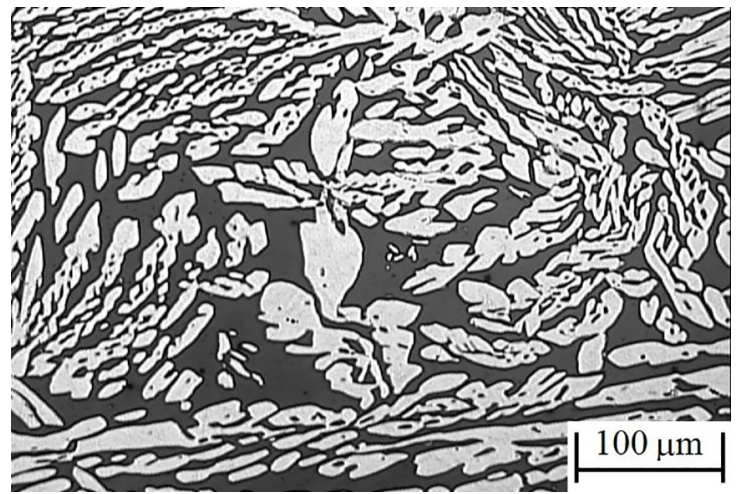

Figure 1. Microstructure of the cast DSS solution treated. Austenite is light and ferrite is dark. Beraha's etching.

\subsection{Impact toughness and hardness}

Figure 2 shows the curves of variation of hardness and impact toughness as function of aging time at $475^{\circ} \mathrm{C}$. It is interesting to note that, differently from previous results on wrought SDSS with low carbon content ${ }^{10}$, the toughness decreases abruptly in the first $4 \mathrm{~h}$ of aging. Unfortunately, the impact toughness decreased considerably in the first 4 hours of aging. The cast DSS studied in this work is highly susceptible to $475^{\circ} \mathrm{C}$ embrittlement, despite of it's low Mo content. Probably, the high carbon content also affects the toughness of the steel.

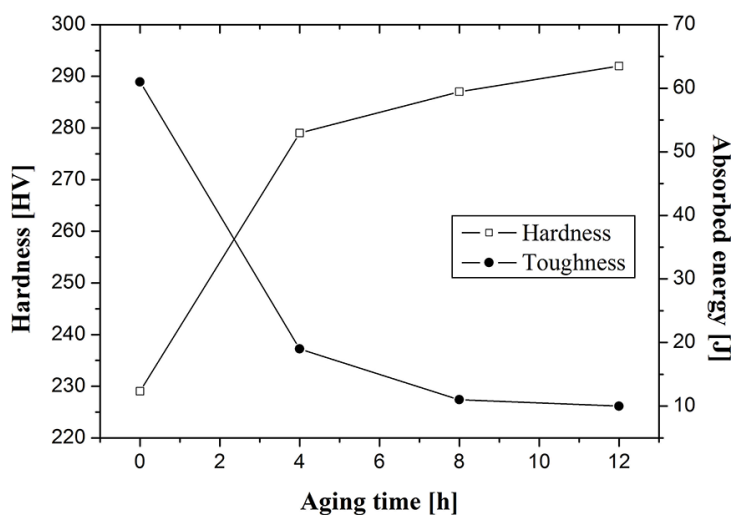

Figure 2. Curves of hardness and toughness as function of aging time at $475{ }^{\circ} \mathrm{C}$.

Figure 3 shows the fracture surfaces of specimens unaged and aged for $12 \mathrm{~h}$. In accordance to the impact energy data, specimen aged for $12 \mathrm{~h}$ show typical brittle behavior, with cleavage facets (Figure 3(d)), while the solution treated and un-aged specimen has a ductile behavior, with dimples (Figure 3(b)). 


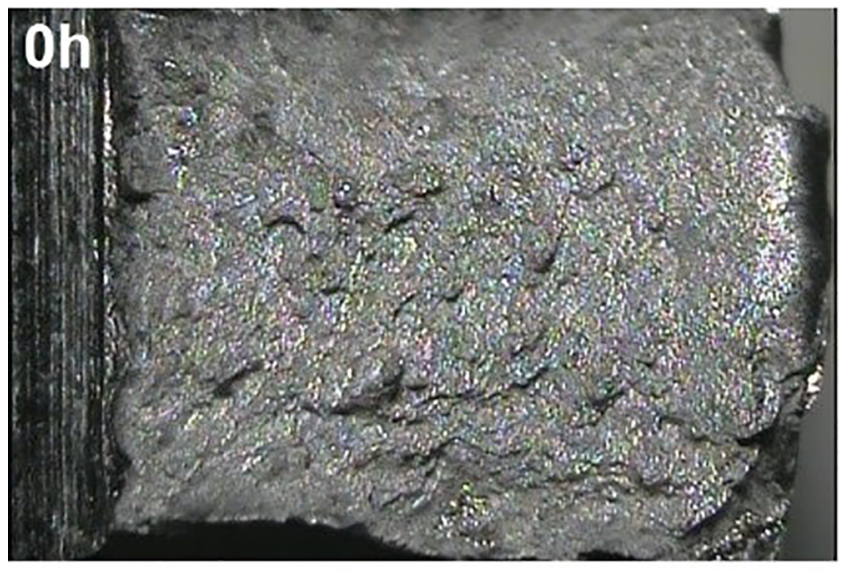

(a)

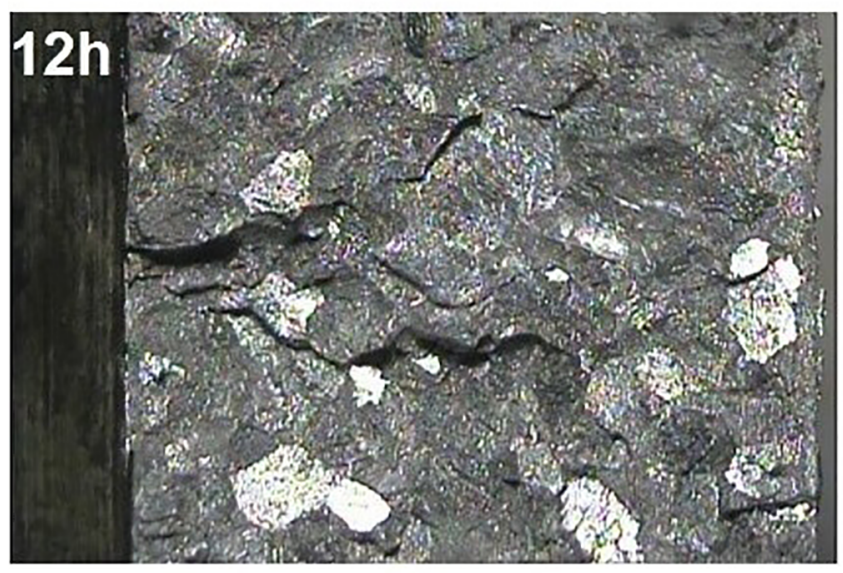

(c)

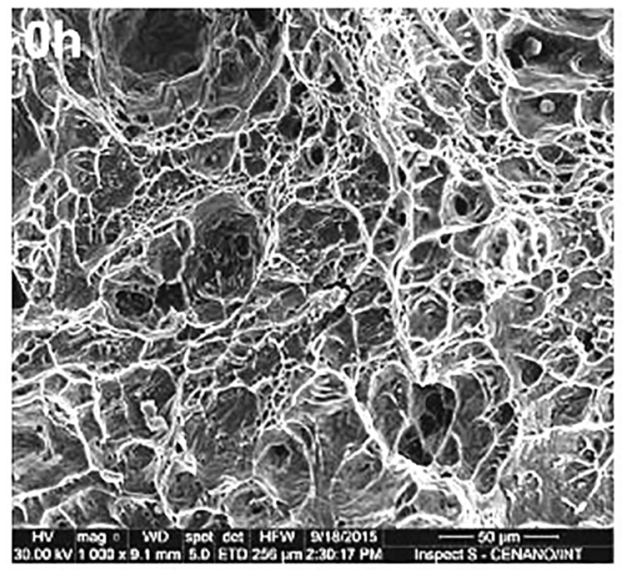

(b)

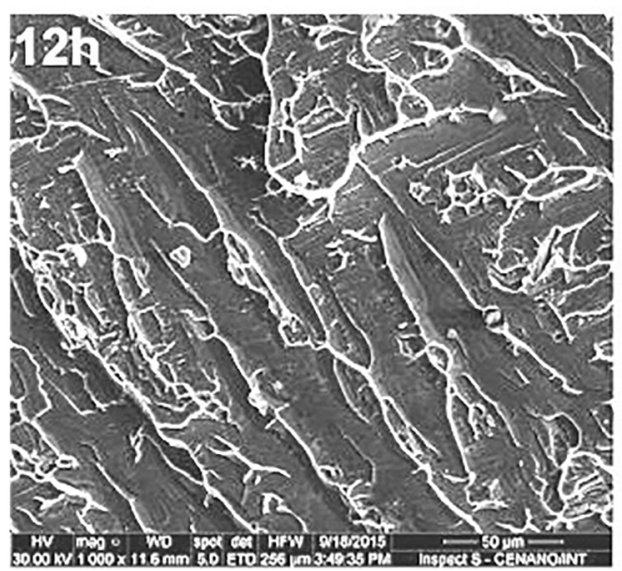

(d)

Figure 3. Fracture surfaces of Charpy specimens: (a-b) solution treated; (c-d) $475{ }^{\circ} \mathrm{C} / 12 \mathrm{~h}$.

\subsection{Corrosion Resistance}

Figure 4 shows the DL-EPR curves of the specimens solution treated, aged at $475^{\circ} \mathrm{C}$ for $4 \mathrm{~h}, 8 \mathrm{~h}$ and $12 \mathrm{~h}$.

The DL-EPR curves of specimens solution treated and aged for $4 \mathrm{~h}$ and $8 \mathrm{~h}$ did not present reactivation peaks, which indicates that in these heat treatment conditions the material was not susceptible to intergranular corrosion. However, the specimen aged for $12 \mathrm{~h}$ presented an Ir/Ia ratio of $0.042(4.2 \%)$, which means that this material is slightly sensitized.

Specimens aged at $475^{\circ} \mathrm{C}$ for $8 \mathrm{~h}$ and $12 \mathrm{~h}$ were observed in the scanning electron microscope (SEM). The specimen aged for $8 \mathrm{~h}$ did not show intergranular corrosion, but the specimen aged for $12 \mathrm{~h}$ shows intergranular attack in the $\delta / \gamma$ interface, as shown in Figure 5(a-d). The particles indicated by arrows in Figs 5(c-d) are chromium carbides precipitated in the aging treatment at $475^{\circ} \mathrm{C}$ for $12 \mathrm{~h}$. The corrosion decay of the high carbon cast DSS studied is rather attributed to these carbides than to the decomposition of ferrite. The chromium

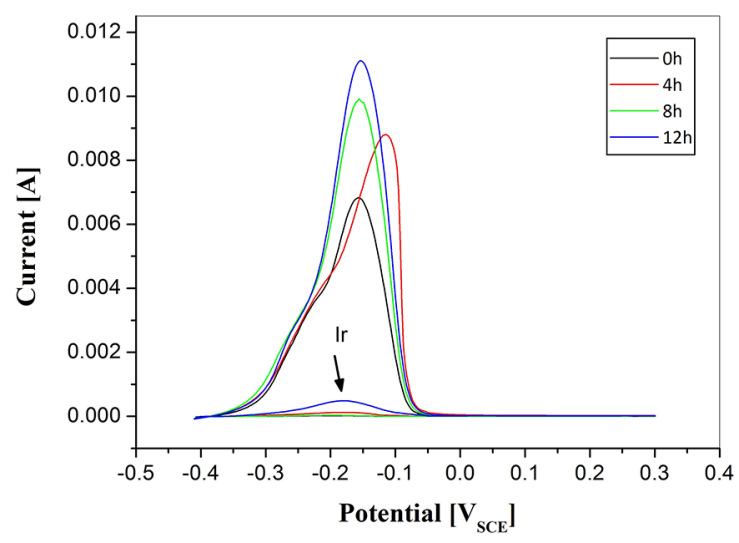

Figure 4. DL-EPR curves of specimens solution treated ( $0 \mathrm{~h})$, aged at $475^{\circ} \mathrm{C}$ for $4 \mathrm{~h}, 8 \mathrm{~h}$ and $12 \mathrm{~h}$.

carbides were not observed in the specimen aged at $8 \mathrm{~h}$. It seems that this deleterious precipitation occurs between 8 $\mathrm{h}$ and $12 \mathrm{~h}$ at $475^{\circ} \mathrm{C}$. 


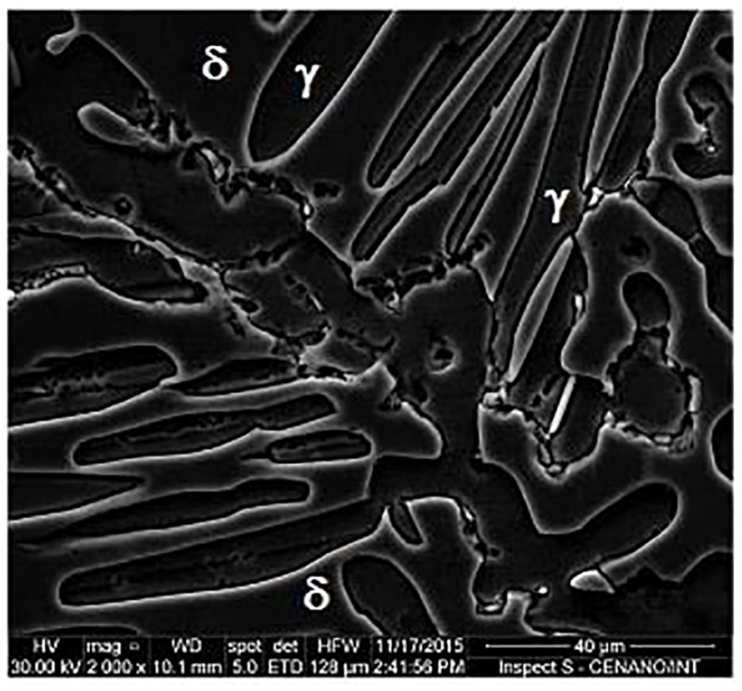

(a)

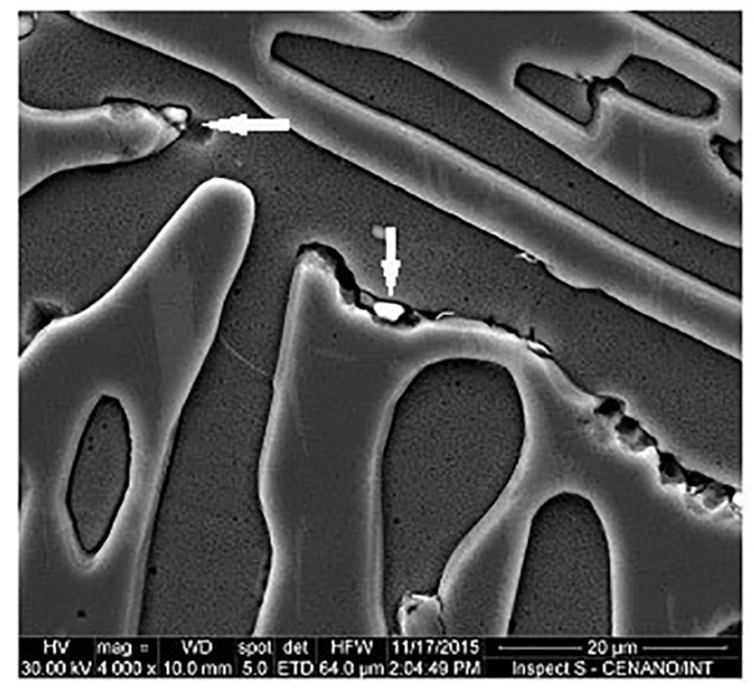

(c)

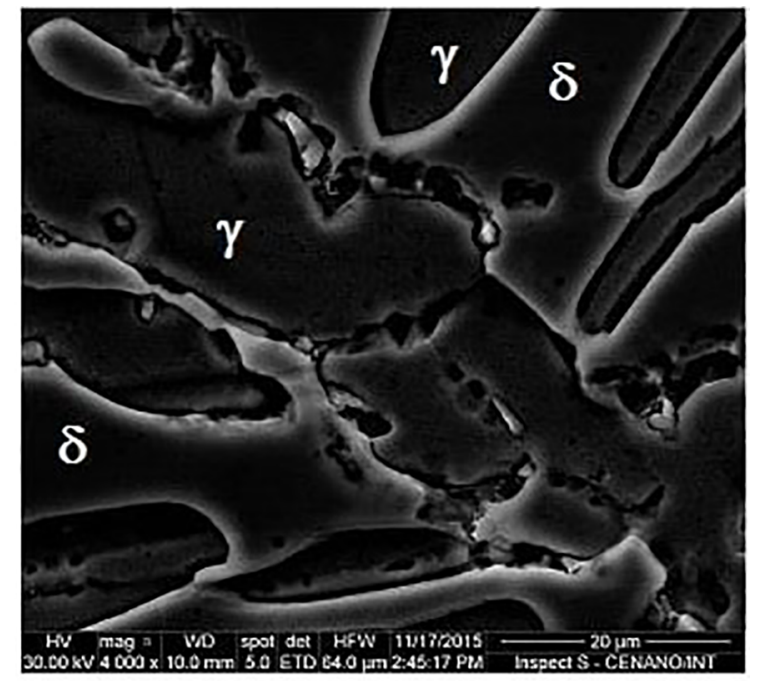

(b)

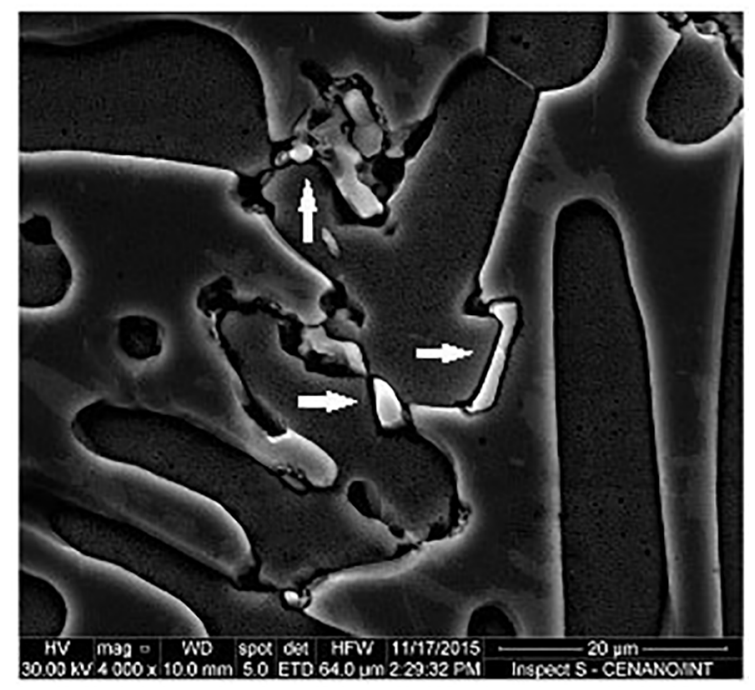

(d)

Figure 5. SEM images, after DL-EPR test in the specimen aged at $475^{\circ} \mathrm{C}$ for $12 \mathrm{~h}$.

\section{Conclusions}

The main conclusions about the effect of thermal aging at $475^{\circ} \mathrm{C}$ of a cast duplex stainless steel are:

- There is a substantial increase on hardness of the analyzed steel in the first 4 hours of thermal aging at $475^{\circ} \mathrm{C}$ as a consequence of the spinodal decomposition of the ferritic matrix;

- The impact toughness decreased considerably in the first 4 hours of aging, at $475^{\circ} \mathrm{C}$, which means that the cast steel analyzed is very susceptible to $\alpha$ formation through $\delta$ decomposition;
- $\quad$ Samples aged at $475^{\circ} \mathrm{C}$ for periods up to $8 \mathrm{~h}$ were not sensitized in DL-EPR tests with $2 \mathrm{M} \mathrm{H}_{2} \mathrm{SO}_{4}$ $+0.01 \mathrm{M} \mathrm{KSCN}+0.5 \mathrm{M} \mathrm{NaCl}$ solution at room temperature. However, the sample aged for 12 hours showed chromium carbides and intergranular corrosion on ferrite/austenite $(\delta / \gamma)$ boundaries. This result is related to higher carbon contents of the steel studied;

- The results show that the mechanical properties, such as toughness and hardness, are more sensitive to aging, having been affected already in the first 4 hours of heat treatment, whereas the corrosion resistance only showed variation after $12 \mathrm{~h}$ of aging. 


\section{References}

1. Gunn RN, ed. Duplex Stainless Steels. Microstructure, Properties And Applications. Cambridge: Abington Publishing; 2003.

2. Pardal JM. Aços Inoxidáveis Superduplex. São Paulo: Blucher; 2012.

3. Norsok Standard. Norsok Standard M-601-16 Welding Specification of piping. Lysaker: Standards Norway; 2016.

4. Reick W, Pohl M, Padilha AF. O Desenvolvimento dos aços inoxidáveis Ferríticos-Austeníticos com Microestrutura Duplex. In: Anais do $47^{\circ}$ Congresso Anual da Associação Brasileira de Metalurgia e Materiais; 1992; Belo Horizonte, MG, Brazil. Belo Horizonte: ABM; 1992;48(409).

5. Muthupandi V, Bala Srinivasan P, Seshadri SK, Sundaresan S. Effect of weld metal chemistry and heat input on the structure and properties of duplex stainless steel welds. Materials Science and Engineering: A. 2003;358(1-2):9-16.

6. Martins AS. Estudo comparativo da resistência à corrosão dos aços inoxidáveis super duplex ASTM A890/A890M Grau $5 A$ e $6 A$. [Dissertação de Mestrado]. Fortaleza: Universidade Federal do Ceará; 2014.
7. Sahu JK, Krupp U, Ghosh RN, Christ HJ. Effect of $475^{\circ} \mathrm{C}$ embrittlement on the mechanical properties of duplex stainless steel. Materials Science and Engineering: A. 2009;508(1-2):1-14.

8. Tavares SSM, Terra VF, De Lima Neto P, Matos DE. Corrosion resistance evaluation of the UNS S31803 duplex stainless steels aged at low temperatures $\left(350\right.$ to $\left.550^{\circ} \mathrm{C}\right)$ using DLEPR tests. Journal of Materials Science. 2005;40(15):4025-4028.

9. Weng KL, Chen HR, Yang JR. The low-temperature aging embrittlement in a 2205 duplex stainless steel. Materials Science and Engineering: A. 2004;379(1-2):119-132.

10. Marques F, Da Silva WM, Pardal JM, Tavares SSM, Scandian C. Influence of heat treatments on the micro-abrasion wear resistance of a superduplex stainless steel. Wear. 2011;271(910):1288-1294.

11. ASTM International. ASTM E23-16b-Standard Test Methods for Notched Bar Impact Testing of Metallic Materials. West Conshohocken: ASTM International; 2016.

12. ASTM International. ASTM A890-13 - Standard Specification for Castings, Iron-Chromium-Nickel-Molybdenum CorrosionResistant, Duplex (Austenitic/Ferritic) for General Application. West Conshohocken: ASTM International; 2013. 